\title{
Comparison of Continuous and Intermittent Intravenous Insulin Therapies for Diabetic Ketoacidosis*
}

\author{
K. M. Piters, D. Kumar, Eva Pei, and Alice N. Bessman \\ From the Department of Medicine, Diabetes Section, University of Southern California School of Medicine, \\ Los Angeles County Medical Centre, Los Angeles, California, USA
}

Summary. Twenty-six diabetic ketoacidotic patients were treated with 3 different intravenous insulin regimes. Group (A) received $50 \mathrm{U}$ initially and at $2 \mathrm{~h}$ intervals. Groups (B) and (C) were given continuous infusions of 10 and $2 \mathrm{U}$ per hour respectively without added albumin. In addition, Group $(\mathrm{C})$ received a loading dose of $3 \mathrm{U}$. The dosages were reduced when serum glucose declined to $300 \mathrm{mg} / 100 \mathrm{ml}$. Criteria for admission to the study included a plasma glucose above $350 \mathrm{mg} / 100 \mathrm{ml}$, plasma bicarbonate less than $9 \mathrm{mmol} / \mathrm{l}$, serum ketone-bodies detectable by nitroprusside test at 8 -fold or greater dilution, and arterial $\mathrm{pH}$ less than 7.3. The rate of normalization of blood glucose, bicarbonate, ketone bodies, and $\mathrm{pH}$ did not differ between Group (A) and (B). In contrast, the changes in $\mathrm{pH}$, glucose, and ketone-bodies were significantly slower in Group (C). Two patients of Group (C) had worsening of these biochemical parameters during the first $6 \mathrm{~h}$. They were treated successfully with regimen A. At $2 \mathrm{~h}$, plasma immunoreactive insulin concentrations were $47 \pm 15,135 \pm 19$, and $25 \pm 3 \mu \mathrm{U} / \mathrm{ml}$ in previously untreated patients in Groups (A), (B) and (C), respectively. Potassium requirements to maintain adequate blood levels were significantly higher in Group (A). The data demonstrate that $10 \mathrm{U} / \mathrm{h}$ infusion of insulin is as effective as $50 \mathrm{U}$ administered intravenously every $2 \mathrm{~h}$. The amount of insulin infused should be reduced to $5 \mathrm{U} / \mathrm{h}$ when plasma glucose has declined to $300 \mathrm{mg} / 100 \mathrm{ml}$. The recovery is slow, plasma insulin concentration is inadequate and treatment failure may occur with very low insulin doses $(2 \mathrm{U} / \mathrm{h})$.

Key words: Diabetic coma, ketoacidosis, intravenous insulin-infusion, ketone-bodies.

\footnotetext{
* Presented at 9th Congress of International Diabetes Federation, New Delhi, India.
}

Traditionally, large doses of insulin in the range of hundreds of units have been advocated [1-4] in the treatment of diabetic ketoacidosis. However, there had been some scepticism over both the necessity for such high doses and the existence of insulin resistance in ketoacidosis that such high doses implied $[5,6]$. This scepticism has recently been revived, as emphasized by Sönksen et al. [7], who found rapid biochemical and clinical improvement in severe diabetic ketoacidosis with insulin infusion rates between 1.5 and $12 \mathrm{U} /$ hour. Alberti et al. [8], showed that relatively small doses of insulin (average $16 \mathrm{U}$ initially and 5 to $10 \mathrm{U}$ hourly) were effective in the treatment of severe diabetic ketoacidosis when given by the intramuscular route.

There have been several reports utilizing low doses of insulin (1.2 to $12 \mathrm{U} /$ hour, with or without an initial priming dose of $0.5-12 \mathrm{U}$ ) by the intravenous route $[9,10,11]$. All groups found their regimes effective in the treatment of ketoacidosis. This literature, however, met with unfavourable criticism [12] primarily because of the lack of a well-defined control group for comparison. Also, the degree of ketoacidosis was minimal in many of the reported cases.

Most recently, Kitabchi et al. [13] studied the efficacy of low-dose (initial $0.1 \mathrm{U}$ per lb. body weight, followed with $5 \mathrm{U} /$ hour) intramuscular insulin therapy. This regime was as effective as a more traditional one. The present study was designed to compare the efficacy of 2 and $10 \mathrm{U} /$ hour intravenous insulin infusions with a conventional treatment, $50 \mathrm{U}$ of insulin administered intravenously at 2 hour intervals. Diagnostic criteria of diabetic ketoacidosis were well-defined. Measurement of plasma ketone bodies was included as an indication of resolution of ketoacidosis. 


\section{Methods}

Patients: Twenty-six patients with diabetic ketoacidosis were studied at the Los Angeles CountyUniversity of Southern California Medical Centre. Their ages were $37 \pm 3$ (SEM) years (range 17 to 79). Eight patients were newly diagnosed diabetics without prior insulin therapy, 16 were insulin-dependent diabetics, and 2 cases had been previously controlled by diet and sulphonylurea drugs.

Patients included in this study met the following criteria: plasma glucose above $350 \mathrm{mg} / 100 \mathrm{ml}$; plasma bicarbonate below $9 \mathrm{mmol} / 1 ; \mathrm{pH}$ less than 7.3 , serum ketone-bodies positive with nitroprusside test in 8-fold or greater dilution, and ketones present in the urine; no insulin therapy during the preceding $24 \mathrm{~h}$ (this criterion was included to avoid superimposition of therapy on recently administered insulin); no clinical evidence of acute myocardial infarction, congestive heart failure, shock or severe infection.

Insulin Therapy: Patients were randomly assigned to one of the 3 insulin regimes. Group (A) intermittent bolus group was comprised of 10 patients who received $50 \mathrm{U}$ regular (crystalline Zinc) insulin intravenously at the beginning, and at 2 hourly intervals. The insulin dose was reduced to $25 \mathrm{U}$ when plasma glucose became $300 \mathrm{mg} / 100 \mathrm{ml}$. Group (B) and $(C)$ were given continuous intravenous infusions of insulin at $10 \mathrm{U} /$ hour (9 cases), and $2 \mathrm{U} /$ hour (7 cases), respectively. Insulin infusion rates were reduced to $5 \mathrm{U} /$ hour in Group (B) when plasma glucose became $300 \mathrm{mg} / 100 \mathrm{ml}$. Group (C) patients were given an intravenous loading dose of $3 \mathrm{U}$. Regular insulin (u-100) was diluted to 2 or $4 \mathrm{U}$ per ml in saline $(0.154 \mathrm{~mol} / 1)$, without adjuvant. Insulin solution was delivered by a syringe pump using a $60 \mathrm{ml}$ polyethylene syringe. Insulin content on sequential aliquots over a 12 -h period were measured [14] in vitro and demonstrated $83 \%$ delivery.

Fluids: Fluid therapy was uniform throughout. Saline $(0.154 \mathrm{~mol} / \mathrm{l})$ was initially administered at rates sufficient to achieve a net-positive balance of $4 \mathrm{l}$ over $12 \mathrm{~h}$. When the plasma glucose reached $300 \mathrm{mg} / 100 \mathrm{ml}$, fluid therapy was changed to glucose $(5 \mathrm{~g} / 100 \mathrm{ml})$ in saline $(0.154 \mathrm{~mol} / \mathrm{l})$ given at rates adequate to keep the plasma glucose above $200 \mathrm{mg} / 100 \mathrm{ml}$. Potassium as $\mathrm{KCl}$ was administered at $20-30 \mathrm{mmol} / \mathrm{l}$ of intravenous fluid when the serum potassium fell below $4.5 \mathrm{mmol} / 1$. Sodium bicarbonate was given to only one patient who received $88 \mathrm{mmol}$ to bring the $\mathrm{pH}$ from 6.9 to 7.1 .
Monitoring: Patients were studied for a 12-hour period beginning at the time of first insulin dose. Plasma glucose, bicarbonate, electrolytes, total serum ketone-bodies (acetoacetate, and 3-hydroxybutyrate) [15] were obtained initially and every 2 hours thereafter. Plasma immunoreactive insulin (IRI) levels [14] were also obtained in those patients previously untreated with insulin. In Group (A), plasma samples for IRI were collected just prior to the next insulin dose. Glucose, electrolytes and $\mathrm{pH}$ were measured by the hospital laboratory. The results for each group were compared by the pooled variant-analysis method with comparison of means by the Student's t-test.

\section{Results}

Groups were well matched in terms of numbers, age, and number of newly diagnosed diabetics. All patients were in severe diabetic ketoacidosis (Table 1) although none were clinically comatose.

\section{Glucose}

The fall in plasma glucose was roughly linear in all groups (Table 1). During the initial $2 \mathrm{~h}$, the plasma glucose declined by $39 \pm 4$ (SEM), $34 \pm 4$, and 23 $\pm 3 \%$ of the initial levels in Groups (A), (B), and (C), respectively. The changes in Groups (A) and (B) were not statistically different, both being significantly greater $(\mathrm{P}<0.05)$ than Group $(\mathrm{C})$. Plasma glucose reached $300 \mathrm{mg} / 100 \mathrm{ml}$ in $3.4 \pm 0.4$ and 4.3 \pm 1.2 hours in Groups (A) and (B) $(\mathrm{P}=$ N. S.). In contrast, Group (C) took longer to reach this level, $7 \mathrm{~h}(\mathrm{P}<0.05)$, with 3 patients not attaining this level by the end of the 12-h study period.

The fluid therapy was started prior to initiation of insulin therapy in 3 patients of Group (B). Plasma glucose fell by a mean of $58 \mathrm{mg} / 100 \mathrm{ml}$ in $1 \mathrm{~h}$ with fluid therapy alone. However, the study period began with the first dose of insulin.

An inability to maintain the plasma glucose above $200 \mathrm{mg} / 100 \mathrm{ml}$ by glucose $(5 \mathrm{~g} / 100 \mathrm{ml})$ infusion occurred in 2 patients of Group (B). It was necessary to reduce the insulin infusion rate to $5 \mathrm{U} /$ hour to avoid hypoglycaemia.

\section{Ketone-Bodies}

The decline in total serum ketone-bodies (3-hydroxybutyrate plus acetoacetate) is given in Table 1 and Figure 1. Statistical analysis of the percent 
Table 1. Effect of treatment on biochemical data in various groups of ketoacidotic patients studied

\begin{tabular}{|c|c|c|c|c|}
\hline Time in $h 0$ & & 2 & 4 & 6 \\
\hline \multicolumn{5}{|c|}{ Serum glucose $\mathrm{mg} / 100 \mathrm{ml}$} \\
\hline Group A & $754 \pm 62$ & $451 \pm 48$ & $322 \pm 43$ & $284 \pm 3$ \\
\hline B & $635 \pm 84$ & $441 \pm 77$ & $331 \pm 55$ & $297 \pm 34$ \\
\hline $\mathrm{C}$ & $671 \pm 95$ & $509 \pm 90$ & $454 \pm 81$ & $392 \pm 84$ \\
\hline
\end{tabular}

Serum potassium ${ }^{\mathrm{a}} \mathrm{mmol} / \mathrm{l}$

$\begin{array}{rrrrrr}\text { Group A } & 4.9 \pm 0.3 & 3.9 \pm 0.2 & 4.3 \pm 0.2 & 4.2 \pm 0.2 & 4.2 \pm 0.2 \\ \text { B } & 4.9 \pm 0.4 & 4.5 \pm 0.2 & 4.3 \pm 0.1 & 4.2 \pm 0.2 & 4.2 \pm 0.3 \\ \text { C } & 5.0 \pm 0.3 & 4.7 \pm 0.2 & 4.3 \pm 0.3 & 4.2 \pm 0.1 & 4.1 \pm 0.2\end{array}$

Serum inorganic phosphate $\mathrm{mg} / 100 \mathrm{ml}$

$\begin{array}{rlllll}\text { Group A } & 5.7 \pm 0.8 & 2.4 \pm 0.4 & 1.6 \pm 0.2 & 1.4 \pm 0.3 & 0.8 \pm 0.1 \\ \text { B } & 6.6 \pm 0.7 & 5.2 \pm 0.7 & 3.1 \pm 0.6 & 2.4 \pm 0.3 & 1.7 \pm 0.3 \\ \text { C } & 4.8 \pm 0.8 & 3.7 \pm 0.5 & 3.0 \pm 0.4 & 2.7 \pm 0.4 & 2.0 \pm 0.3\end{array}$

Serum bicarbonate $\mathrm{mmol} / \mathrm{I}$

$\begin{array}{rlllll}\text { Group A } & 5.8 \pm 0.8 & 7.0 \pm 1.0 & 10.5 \pm 1.6 & 12.6 \pm 2.3 & 17.0 \pm 2.0 \\ \text { B } & 6.2 \pm 0.7 & 8.5 \pm 0.8 & 10.8 \pm 1.0 & 12.1 \pm 0.8 & 18.4 \pm 1.7 \\ \text { C } & 7.4 \pm 1.0 & 9.4 \pm 1.5 & 10.0 \pm 2.3 & 10.7 \pm 1.9 & 14.8 \pm 2.6\end{array}$

Ketone-bodies $^{\mathrm{b}} \mathrm{mmol} / \mathrm{l}$

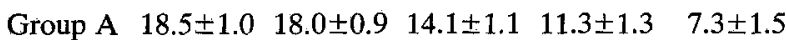

$\begin{array}{llllll}\text { B } & 16.5 \pm 1.3 & 13.2 \pm 1.3 & 12.6 \pm 1.0 & 9.2 \pm 1.2 & 5.5 \pm 0.7\end{array}$

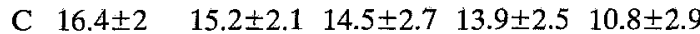

Blood $\mathrm{pH}^{\mathrm{c}}$

Group A $7.14 \pm 0.04$

B $7.14 \pm 0.04$

$7.28 \pm 0.057 .36 \pm 0.03$

C $7.19 \pm 0.04$

$7.30 \pm 0.037 .37 \pm 0.02$

$7.26 \pm 0.057 .28 \pm 0.04$

Values are Mean \pm SEM

Group A received $50 \mathrm{U}$ insulin intravenously every $2 \mathrm{~h}$. Group B, and $C$ were given continuous intravenous infusions of 10 and $2 \mathrm{U} /$ hour respectively.

a Patients received intravenous infusions of $\mathrm{KCl}$ when serum potassium was $<4.5 \mathrm{mmol} / \mathrm{l}$. The amounts of potassium infused were $146 \pm 17^{\mathrm{d}}, 77 \pm 11$ and $80 \pm 8 \mathrm{mmol}$ in Groups $\mathrm{A}, \mathrm{B}$, and $\mathrm{C}$ respectively.

b Ketone-bodies (acetoacetate +3 -hydroxybutyrate)

c Blood $\mathrm{pH}$ was arterial at $0 \mathrm{~h}$. Subsequent readings were mostly on venous blood samples.

${ }^{d} \mathbf{P}<0.05$ compared to other groups.

decline in total serum ketone bodies in 3 groups reveals that, at both 6 and $12 \mathrm{~h}$, Group (C) had a slower improvement $(P<0.05)$ than either Groups (A) or (B). Groups (A) and (B) were not significantly different from each other.

\section{pH}

The improvements in $\mathrm{pH}$ are given in Table 1 . The changes in Group (C) were significantly slower $(\mathrm{P}<0.05)$ compared to other groups.
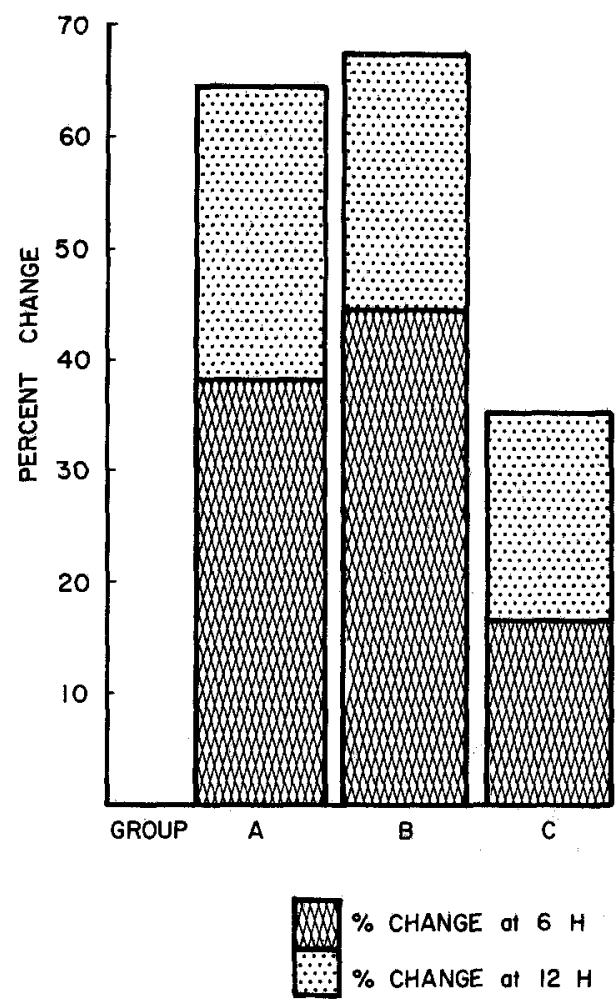

Figure 1. Percent decline in total ketone-bodies at 6 and $12 \mathrm{~h}$. Changes were slower $(\mathrm{P}<0.05)$ in Group $(\mathrm{C})$ compared to Groups (A) and (B)

\section{Bicarbonate}

The changes observed in serum bicarbonate concentrations are summarized in Table 1. Group (C) had slower improvement in serum bicarbonate levels; however, this was not significant statistically. The time required to improve serum bicarbonate to $15 \mathrm{mmol} / \mathrm{l}$ was $8.9 \pm 1.7$ and $8.3 \pm 1 \mathrm{~h}$ in Groups (A) and (B) respectively. In Group (C), there were 3 patients where serum bicarbonate remained less than $15 \mathrm{mmol} / \mathrm{l}$ even at 12 -h.

\section{Serum Potassium}

On admission there was wide variation in serum potassium concentrations. It ranged from 3 to $6.8 \mathrm{mmol} / 1$. As per protocol intravenous potassium was administered when serum potassium was $<4.5 \mathrm{mmol} / \mathrm{l}$. Several patients thus received potassium therapy in the first hour, and almost all of them were getting it by the 5th hour. The sequential changes in various groups and the amounts of potassium given are summarized in Table 1. Group (A) required more potassium replacement to maintain 
adequate blood levels $(\mathrm{P}<0.01)$. Unfortunately, potassium lost in urine was not monitored.

\section{Plasma Immunoreactive Insulin (IRI) Levels}

Only patients without prior insulin therapy were studied. At 0 time, IRI was $9 \pm 2 \mu \mathrm{U} / \mathrm{ml}$ in all groups. In Group A ( 3 cases), the IRI levels were $47 \pm 15 \mu \mathrm{U} / \mathrm{ml}$ at $2 \mathrm{~h}, 66 \pm 21 \mu \mathrm{U} / \mathrm{ml}$ at $4 \mathrm{~h}$, and $54 \pm 26 \mu \mathrm{U} / \mathrm{ml}$ at $6 \mathrm{~h}$. Insulin delivered at $10 \mathrm{U} /$ hour achieved steady state serum levels of 135 $\pm 19,124 \pm 17$, and $136 \pm 21 \mu \mathrm{U} / \mathrm{ml}$ at 2,4 and $6 \mathrm{~h}$ respectively in 3 cases, and delivery at $2 \mathrm{U} /$ hour achieved levels of $25 \pm 3,25 \pm 4$, and $23 \pm$ $6 \mu \mathrm{U} / \mathrm{ml}$ at 2,4 , and $6 \mathrm{~h}$ respectively in 4 cases.

\section{Failures and Complications}

There were two "treatment failures" in Group (C), where plasma total ketone-bodies remained unchanged and $\mathrm{pH}$ and bicarbonate levels deteriorated slightly. The plasma glucose, however, declined by $30.5 \%$ of the initial value in first $2 \mathrm{~h}$. Both patients were juvenile diabetics, one being a newly diagnosed man and the other an insulin-dependent woman. These patients did not differ clinically at the onset from those patients who responded more promptly. They were eventually treated with boluses of $50 \mathrm{U}$ of insulin administered intravenously every $2 \mathrm{~h}$. These two cases and all others had resolution of their diabetic ketoacidosis and recovered without complications or sequelae.

\section{Discussion}

Previous investigators $[9,10,11]$ had reported successful treatment of diabetic ketoacidosis using infusion rates of 1.2 to $12 \mathrm{U} /$ hour. However, in these studies no comparisons were made with conventional high-dose treated patients. Also, several patients did not meet the biochemical diagnostic criteria of ketoacidosis [12].

We report a controlled, randomized study which compares three intravenous insulin regimes. All patients treated with $50 \mathrm{U}$ insulin every $2 \mathrm{~h}$ (Group A) and insulin infusion at a rate of $10 \mathrm{U} /$ hour (Group B) showed relatively rapid resolution of the biochemical markers of ketoacidosis. The recovery rates in these two groups were identical. In contrast, the recovery rates were significantly slower in patients treated with $2 \mathrm{U}$ /hour infusions (Group C). There were two treatment failures in this group. Re- cently, Clumeck et al. [16] have also reported two cases who had inadequate biochemical response to $5 \mathrm{U}$ of insulin administered intravenously every hour. Therefore, very low doses of insulin $(<5 \mathrm{U} /$ hour) should not be used for adult patients in severe diabetic ketoacidosis.

Infusions of very small amounts of insulin, 1 [17] and $1.2 \mathrm{U} /$ hour [10], have produced lowering of blood glucose in diabetic patients. Also, insulin in moderate concentration of $25 \mu \mathrm{U} / \mathrm{ml}$ inhibits lipolysis in isolated rat fat cells [18]. These would suggest that the IRI levels of $25 \pm 3 \mu \mathrm{U} / \mathrm{ml} \mathrm{ob}$ served in our $2 \mathrm{U} /$ hour infusion Group (C) could be considered satisfactory. However, two "treatment failures" and slower resolution of ketoacidosis in this group would indicate the inadequacy of such plasma IRI concentrations therapeutically. The nadirs of plasma IRI concentrations in Group (A), the intermittent insulin treated group, were 47 to $66 \mu \mathrm{U} / \mathrm{ml}$. These were 2 to 3 -fold higher than the steady state levels in Group (C). The peak IRI levels would be much higher. In Group B (10 U/hour infusion group), IRI levels were $135 \pm$ $19 \mu \mathrm{U} / \mathrm{ml}$. These would seem therapeutically desirable concentrations because these are close to the portal vein insulin levels found 7 to 17 minutes postglucose load in man [19]. Such insulin concentrations are effective in inhibiting glycogenolysis, and in reducing gluconeogenesis in the liver [20].

Soler et al. [21] report that the small doses of insulin administered intravenously (8 U/hour infusion) or intramuscularly ( $10 \mathrm{U} /$ hour $)$ led to a slower recovery from ketoacidosis, when compared retrospectively with a group treated with large intravenous boluses of insulin. In fact, their groups were not significantly different, when serum bicarbonate level of $<20 \mathrm{mmol} / 1$ was the criterion for the resolution of ketoacidosis.

We monitored plasma potassium carefully, and hypokalaemia was not a problem in any of our cases. Potassium supplements required to maintain adequate blood levels were significantly higher in Group (A) compared to others. It has been stated previously that large doses of insulin lead to faster fall of plasma potassium [11]. Our observations disagree with those of Soler et al. [21], who reported identical potassium needs in patients treated with low or high insulin doses. Unfortunately, potassium lost in the urine was not monitored and we were unable to determine the amounts of potassium retained during $12 \mathrm{~h}$ period in various groups.

The current study demonstrated once again that hydration alone affects plasma glucose [8]. There was a gradual and linear fall in plasma glucose in all patients, even in those who showed no change in 
plasma ketone-bodies, bicarbonate and $\mathrm{pH}$. This disparity between the response of plasma glucose and the response of the biochemical markers of ketoacidosis illustrates the danger of using the fall in plasma glucose alone as an indication of therapeutic success.

Continuous intravenous infusion as a therapeutic modality is currently accepted for such drugs as heparin and certain antibiotics, where constant serum levels are desirable and where prompt cessation of action of the administered drug may become medically advisable. The intravenous infusion of insulin has such advantages over intramuscular, subcutaneous and intermittent intravenous modes of insulin therapy. Evenness of delivery, absorption of full dose assured (especially pertinent in the hypotensive patient), abrupt cessation of effect upon discontinuance of delivery, lack of repeated injections for the patient, and predictable linear changes in most biochemical variables are among these advantages.

We feel that continuous intravenous insulin infusion has a place in the treatment of diabetic ketoacidosis. An infusion of $10 \mathrm{U} /$ hour is effective, but the dose should be reduced to $5 \mathrm{U} / \mathrm{h}$ when plasma glucose has fallen to $300 \mathrm{mg} / 100 \mathrm{ml}$. It must be re-emphasized that any method employed must be carefully monitored and individually adjusted.

Acknowledgements. The authors wish to thank the house-staff of the Diabetes Service of the Los Angeles County-University of Southern California Medical Centre for their assistance and cooperation. The technical assistance of Ms. Jetty Page and Ms. Rosemarie Nimo, and secretarial help of Ms. Wendy Berry is very much appreciated.

\section{Refierences}

1. Felig, P.: Diabetic ketoacidosis. N. Engl. J. Med. 290 , 1365-1369 (1974)

2. Genuth, S. M.: Constant intravenous insulin infusion in diabetic ketoacidosis. J. A. M. A. 233, 1348-1351 (1973)

3. Hockaday, T.D.R., Alberti, K.G.M.M.: Diabetic coma. Clin. Endocrinol. Metabol. 1, 751-788 (1972)

4. Winegrad, A.I., Clements, R.S.: Diabetic ketoacidosis. Med. Clin. North Am. 55, 899-911 (1971)

5. Shaw, C.S., Hurwitz, G. E., Schmukler, M., Brager, S.H., Bessman, S. P.: A clinical and laboratory study of insulin dosage in diabetic acidosis: Comparison with small and large doses. Diabetes 11, 23-30 (1962)

6. Smith, K., Martin, H. E.: Responses of diabetic coma to various insulin dosages. Diabetes 3, 287-295 (1954)
7. Sönksen, P.H., Srivastava, M. C., Tompkins, C. V., Nabarro, J.D.N.: Growth hormone and cortisol responses to insulin infusion in patients with diabetes mellitus. Lancet 1972 II, $155-160$

8. Alberti, K. G.M.M., Hockaday, T.D., Tumer, R. C.: Small doses of intramuscular insulin in the treatment of diabetic "coma". Lancet 1973 II, 515-522

9. Semple, P.F., White, C., Manderson, W. G.: Continuous intravenous infusion of small doses of insulin in the treatment of diabetic ketoacidosis. Br. Med. J. 1974 II, 694-698

10. Kidson, W., Casey, J., Kraegen, E., Lazarus, L.: Treatment of severe diabetes mellitus by insulin infusion. Br. Med. J. 1974 II, 691-694

11. Page, M.McB., Alberti, K.G.M.M., Greenwood, R., Gumaa, K. A., Hockaday, T.D.R., Lowy, C., Nabarro, J.D. N., Pyke, D.A., Sönksen, P.H., Watkins, P.J., West, T.E.T.: Treatment of diabetic coma with continuous lowdose infusion of insulin. Br. Med. J. 1974 II, 687-690

12. Madison, L.L.: Low dose insulin: A plea for caution. N. Engl. J. Med. 294, 393-394 (1976)

13. Kitabchi, A.E., Ayyagari, V., Guerra, S.M.O., Medical House Staff: The efficacy of low-dose versus conventional therapy of insulin for treatment of diabetic ketoacidosis. Ann. Intern. Med. 84, 633-638 (1976)

14. Hales, C.N., Randle, P.J.: Assay of insulin with insulin antibody precipitate. Biochem. J. 88, 137-146 (1963)

15. Bessman, S.P., Anderson, M.: Estimation of citric acid and ketone bodies by the salicylaldehyde acetone reaction. Fed. Proc. 16, 154 (1957)

16. Clumeck, N., Troyer, A.D., Naeije, R., Somers, G., Smekens, L., Balasse, E. O.: Treatment of diabetic coma with small intravenous insulin boluses. Br. Med. J. 1976 II, 394-396

17. Lundbaek, K., Christensen, S. E., Hansen, Aa. P., Iversen, J., Ørskov, H., Seyer-Hensen, K., Alberti, K.G.M.M., Whitefoot, R.: Failure of somatostatin to correct manifest diabetic ketoacidosis. Lancet 1976 I, 215-218

18. Lavis, V.R., Ensinck, J.W., Williams, R.H.: Effects of insulin and proinsulin on isolated fat celis and hemidiaphragms from rats. Endocrinology 87, 135-42 (1970)

19. Horwitz, D.L., Starr, J. I., Mako, M.E., Blackard, W.G., Rubenstein, A.H.: Proinsulin, insulin and C-peptide concentrations in human portal and peripheral blood. J. Clin. Invest. 55, 1278-1283 (1975)

20. Felig, P., Wahren, J.: Influence of endogenous insulin secretion on splanchnic glucose and amino acid metabolism in man. J. Clin. Invest. 50, 1702-1711 (1971)

21. Soler, N. G., Wright, A.D., Fitzgerald, M. G., Malins, J. M.: Comparative study of different insulin regimens in management of diabetic ketoacidosis. Lancet 1975 II, 1221-1224

Received: January 5, 1977, and in revised form: March 14, 1977

Alice N. Bessman, M. D.

Associate Professor of Medicine

USC-School of Medicine

Rancho Los Amigos Hospital

7601 East Imperial Highway

Downey, CA 90242

USA 